Художньо-педагогічні завдання.

Мета: усвідомлення вивченого твору з точки зору його використання в шкільній практиці. Формування вміння адаптувати набуті знання про музичний твір до практики музичноестетичного виховання учнів.

Приклад: визначте, у якому класі, при вивченні якої теми можна використати музичний твір. Визначте його художньо-педагогічну доцільність.

Проблема надання виконавській підготовці майбутнього вчителя музики професійнопедагогічного спрямування, незважаючи на певні напрацювання в цьому напрямку, не втрачає своєї актуальності. Як показало наше дослідження, за умови цілеспрямованої і систематичної роботи у класі інструментальної підготовки в умовах індивідуального навчання цей процес може бути ефективним.

Проблема професійно-педагогічної спрямованості виконавської підготовки майбутніх учителів-музикантів $є$ багатоаспектною. Ї̈ розв'язання пов'язано $з$ усіма дисциплінами виконавського циклу, а саме: «Вокальний клас», «Диригування», «Концертмейстерський клас», «Додатковий музичний інструмент».

\title{
Література
}

1. Арчажникова Л. Г. Профессия - учитель музыки : [кн. для учителя] / Л. Г. Арчажникова. - М. : Просвещение, 1984. - 111 с. 2. Кабалевский Д. Б. Воспитание ума и сердце: [кн. для учит.] / Дмитрий Борисович Кабалевский. - М. : Просвещение, 1984. - 206 с. 3. Медушевский В. В. Музыка в семье искусств / В. В. Медушевский // Музыка в школе. - 1984. - № 1. - С. 31-35. 4. Ніколаї Ю. Г. Деякі аспекти формування професійних умінь та навичок студентів у процесі їх інструментальної підготовки // Актуальні питання професійної підготовки вчителя: [ зб. наук. статей]. - М., 1990. С. 143-149. 5. Падалка Г. М. Педагогіка мистецтва (Теорія і методика викладання мистецьких дисциплін) / Галина Микитівна Падалка. - К. : Освіта України, 2008. - 274 с. 6. Платонов К. К. Система психологии и теория отражения / К. К. Платонов. - М. : Наука, 1982. - 309 с.

Вікторія Ревенко

\section{ІНТЕРАКТИВНІ ТЕХНОЛОГІЇ ЯК ЗАСІБ ФОРМУВАННЯ ГРАМАТИЧНОӤ КОМПЕТЕНЦІЇ МАЙБУТНІХ УЧИТЕЛІВ ІНОЗЕМНИХ МОВ}

Ревенко В. В. Інтерактивні технології як засіб формування граматичної компетенції майбутніх учителів іноземних мов.

У статті розглянуто можливості інтерактивних технологій як засобу формування граматичної компетенції майбутніх учителів іноземних мов. Автором наводяться приклади використання деяких інтерактивних методів на заняттях з практичної граматики англійської мови.

Ключові слова: інтерактивні технології, інтерактивні методи, граматична компетенція.

Ревенко В.В. Интерактивные технологии как средство формирования грамматической компетенции будущих учителей иностранных языков.

В статье рассмотрены возможности интерактивных технологий как способа формирования грамматической компетенции будущих учителей иностранных языков. Автор приводит примеры использования некоторых интерактивных методов на занятиях по практической грамматике английского языка.

Ключевые слова: интерактивные технологии, интерактивные методы, грамматическая компетенция.

Revenco V. V. Interactive technologies as a means of forming grammatical competence of future teachers of foreign languages.

In the article the possibilities of interactive technologies as a means of developing future teachers' grammar competence are analyzed. The author gives examples of using of interactive methods at the lessons of practical grammar of English.

Key words: interactive technologies, interactive methods, grammar competence.

Соціально-економічні перетворення в сучасній Україні зумовлюють необхідність реформування системи вищої освіти. Зростають вимоги до рівня професійної компетентності 
майбутнього вчителя, зокрема вчителя іноземних мов. I тому нині актуальним $\epsilon$ впровадження інноваційних технологій навчання, зокрема інтерактивних, що дозволяють досягти якісно нового рівня професійної підготовки майбутнього фахівця. Як показує дійсність, на сучасному етапі розвитку педагогічної науки великий розвивальний та навчальний потенціал інтерактивних технологій розкрито лише частково. Можна говорити про відсутність у широкій практиці науково-методичної літератури щодо використання інтерактивних технологій під час навчання майбутніх учителів-словесників, зокрема у процесі формування їхньої граматичної компетенції. Це не надає змогу студентам належним чином застосовувати на практиці набуті знання та зумовлює результативність навчання.

Загальнодидактичний аспект інтерактивних технологій вивчають В. Гузєєв, М. Кларін, Л. Пироженко, О. Пометун, В. Симоненко Н. Фомін та ін. Методичному аспекту використання інтерактивного навчання під час викладання біології, математики, історії присвячені дослідження Д. Біди，О.Біди， Л. Богданової， Г. Довгань， Г. Коберник， І. Маркової， Г. П’ятакової. Питанню формування іншомовної комунікативної компетенції присвячено дослідження О. Бігич, Н. Бориско, С. Гапонової, С. Ніколаєвої, Ю. Пассова, Н. Скляренко, С. Смоліної, А. Щукіна та ін.

Мета статті полягає у виявленні можливостей інтерактивних технологій у формуванні граматичної компетенції майбутніх учителів іноземних мов як складника іншомовної комунікативної компетенції.

В останнє десятиріччя збільшується інтерес до застосування інтерактивних технологій у процесі навчання. Ми розуміємо інтерактивні технології навчання як технології, що забезпечують активний характер взаємодії учасників навчального процесу на засадах співпраці та співтворчості, що передбачають використання певних інтерактивних методів, прийомів, форм і засобів навчання. Перевагою інтерактивних технологій під час вивчення іноземної мови $\epsilon$ те, що вони сприяють більш активному залученню до роботи, надають змогу більш якісного опанування лексичним та граматичним матеріалом через негайне застосування на практиці отриманих знань. Завдяки наявності активної співпраці, суб'єкт-суб'єктного характеру взаємодії між учасниками процесу навчання інтерактивні технології мають велику значущість у забезпеченні результативності навчання, оскільки $є$ одним із засобів формування багатьох складників професійної компетентності майбутніх учителів іноземних мов. На думку дослідників, володіння іншомовною граматичною компетенцією передбачає засвоєння граматичних знань і формування мовленнєвих граматичних навичок аудіювання й читання (рецептивні навички) та говоріння i письма (репродуктивні навички) [3]. Практика показує, що засвоєння нових граматичних структур здебільшого відбувається шляхом виконання підстановчих вправ, вправ на імітацію, трансформацію, переклад, що призводить до несвідомого засвоєння знань, відсутності готовності більшості студентів самостійно використовувати вивчені ними граматичні структури в умовах, наближених до ситуацій реального спілкування. Недостатньо уваги приділяється етапу практики у спілкуванні задля використання засвоєного матеріалу в процесі усного мовлення.

Наші спостереження свідчать про те, що на заняттях із практичної граматики англійської мови переважна більшість викладачів планує виконання вправ рецептивно-репродуктивного характеру (65\%), а продуктивні, комунікативні вправи пошукового та творчого характеру, що передбачають використання інтерактивних методів, складають лише $35 \%$.

У зв'язку із вказаним вище під час експериментальної роботи нами вносилися зміни до форми проведення занять із практичної граматики англійської мови для студентів I курсу факультету іноземних мов. Поділяючи позицію О. Вовк, Г. Китайгородської, Ю. Пассова, Н. Скляренко, ми намагалися дотримуватися таких основних методичних вимог до завдань 3 формування граматичної компетенції, як: умотивованість, комунікативність, колективні форми організації вправ, наявність ігрового компоненту, змістовність, професійно-педагогічна спрямованість. Згідно з етапами формування навичок і вмінь мовлення ми вважали за доцільне застосовувати інтерактивні технології на етапі автоматизації дій студентів із граматичними структурами під час виконання репродуктивних та продуктивних вправ.

Під час занять ми використовували різні форми педагогічної взаємодії в системі «студентстудент», «викладач-студент(и)», «студент-мінігрупа», «студент-академгрупа». Крім цього, ми дотримувалися визначених та експериментально перевірених дидактичних умов застосування інтерактивних технологій у процесі навчання майбутніх учителів іноземних мов, одна 3 яких це комплексне та систематичне застосування інтерактивних методів. 
Наведемо приклади навчальних завдань із практичної граматики для студентів I курсу під час вивчення теми «The Adjective. Degrees of Comparison», що передбачали використання інтерактивних методів.

Робота в парах «Guess the country»

Meта: формувати навички самостійного вживання нової граматичної структури в усному мовленні; формувати вміння взаємодіяти з достатнім ступенем вільності, надаючи інформацію та звертаючись із запитами щодо надання інформації, у межах теми, запропонованої викладачем.

Завдання: порівняти в парі зі співрозмовником дві країни, використовуючи список прикметників, наданий викладачем (big, small, developed, green, hot, cold, mountainous, expensive, football crazy, safe).

Зразок:

S1: Germany is bigger than Italy.

S2: You are quite right. Moreover, these countries are the most developed in Europe.

\section{Робота в малих групах «Compare two countries»}

Meта: формувати навички самостійного вживання нової граматичної структури в усному мовленні; формувати вміння вести бесіду в межах теми, запропонованої викладачем.

Завдання: в групах з 3-4 чол. обговорити питання, запропоновані викладачем:

1. Is the UK\USA hotter or colder than your country? How much?

2. Is it cheaper\more expensive?

3. What are the differences between your country and the UK\USA?

4. Which things are better in your country than in the UK\USA?

\section{Ажурна пилка}

Meта: формувати навички самостійного вживання нової граматичної структури в усному мовленні; формувати вміння аргументувати думку, реагувати на думку співрозмовника в межах різних тем.

Завдання: в двох командах студенти складають по 10 речень, що містять прикметник, наприклад: «Liverpool is a good football team». Потім представник кожної команди промовляє речення, а представник іншої команди повинен на нього негайно відреагувати, використавши прикметник зі ступенем порівняння. Наприклад: «Yes, but Barcelona is better».

\section{Робота в парах «Favourites»}

Meта: формувати навички самостійного вживання нової граматичної структури в усному мовленні; формувати вміння обмінюватися інформацією за різним спектром питань.

Завдання: в парах розповісти один одному про найулюбленіші речі, використовуючи прикметники вищого та найвищого ступеня. Наприклад: I like crime novels because they usually have the most exciting stories.

Ідеї, що пропонуються: book, song, film, sport, vegetable, actor, animal, café, person, drink.

\section{Робота в малих групах}

Meта: формувати навички самостійного вживання нової граматичної структури в усному мовленні; формувати вміння обмінюватися інформацією за різним спектром питань.

Завдання: поділившись на групи 3-4 чол., студенти мають обрати категорію та в межах цієї категорії скласти якомога більше речень, що містять ступінь порівняння прикметника. Категорії, що пропонуються: animals, countries, sports, means of transport.

Наприклад:

Dogs are more intelligent than cats.

Виграє команда, що має найбільше граматично правильних порівнянь.

\section{Мозковий штурм}

Meта: формувати навички самостійного вживання нової граматичної структури в усному мовленні; формувати вміння взаємодіяти з достатнім ступенем вільності, надаючи інформацію та звертаючись із запитами щодо надання інформації, в межах теми, запропонованої викладачем.

Завдання: студенти мають скласти продовження речень, запропонованих викладачем, що мають ступені порівняння, та висловити їх по черзі, продовжуючи думку попереднього виступаючого.

Приклади речень: 
The more you study...

The more he drinks...

The less you know...

The cheaper the hotel...

The more interesting the work...

Робота в малих групах

Meта: формувати навички самостійного вживання нової граматичної структури в усному мовленні; формувати вміння обмінюватися інформацією за різним спектром питань.

Завдання: поділившись на групи по 3-4 чол., студенти мають знайти відмінні риси між малюнком А та малюнком В і висловитися, використовуючи ступені порівняння. Кожне правильне речення додає 1 бал команді. Виграє команда, що збирає найбільшу кількість балів.

Наприклад:

Team A S1: There are more pictures on the walls.

Team B S1: There are fewer pictures on the walls.

Виграє команда, що має найбільшу кількість правильних порівнянь.

Робота над проектом «Advertising agency»

Meта: формувати навички самостійного вживання нової граматичної структури в усному мовленні; формувати вміння взаємодіяти 3 достатнім ступенем вільності, надаючи інформацію та звертаючись із запитами щодо надання інформації в межах теми, запропонованої викладачем.

Завдання: студенти мають розподілитися на малі групи по 3-4 чол., скласти рекламне оголошення про один 3 нових товарів, провести його презентацію, пояснивши, чому саме цей товар є кращим за інший. Наприклад: For the whitest teeth buy "Colgate». It whitens your teeth and leaves your breath fresher than mountain air. It is more effective than all its leading competitors. Choose «Colgate» for the brightest, more confident smile.

Як показали результати дослідно-експериментальної роботи, завдяки застосуванню інтерактивних технологій відбувається більш ефективне засвоєння нових граматичних структур, розвиваються мовленнєві уміння. Комунікативний характер вправ допомагає студентам практично застосовувати засвоєні граматичні структури, підвищує інтерес до вивчення англійської мови.

\section{Література}

1. Вовк О. І. Формування англомовної граматичної компетенції у майбутніх учителів в умовах інтенсивного навчання: автореф. дис. на здобуття наук. ступеня канд. пед. наук: спец. 13.00.02 «Теорія та методика навчання: германські мови» / О. І. Вовк. - К., 2008. - 19 с. 2. Методика викладання іноземних мов у середніх навчальних закладах: [підручник] / [О. Б. Бігич, Н. О. Бражник, С. В. Гапонова та ін.]; під керівн. С. Ю. Ніколаєвої. - [2-е вид.]. - К. : Ленвіт, 2002. - 328 с. 3. Методика формування міжкультурної іншомовної комунікативної компетенції: Курс лекцій: [навч.метод. посіб. для студ.] / Бігич О. Б., Бориско Н. Ф., Борецька Г. Е. та ін. / за ред. С. Ю. Ніколаєвої. К. : Ленвіт, 2010. - 332 c. 4. Seymour D. 700 classroom activities / David Seymour \& Maria Popova. Macmillan education, 2003. - 154 p. 5. Evans V. Round-Up / Virginia Evans. - Longman, 2009. - 209 p.

\section{РОЗВИТОК НАВИЧОК КОНСУЛЬТУВАННЯ МАЙБУТНІХ СОЦІАЛЬНИХ ПРАЦІВНИКІВ У ПРОЦЕСІ ВИВЧЕННЯ ФАХОВИХ ДИСЦИПЛІН}

Романовська Л. І. Розвиток навичок консультування майбутніх соціальних працівників у процесі вивчення фахових дисциплін.

У статті розглянуто питання підготовки майбутніх соціальних працівників до соціального консультування. Консультування розглядається як кваліфікована допомога особам, які зазнають певних труднощів, задля відновлення й оптимізації їхніх соціальних функцій, умов життєдіяльності. Основною формою підготовки обрано тренінг, який розглядається як система вправ, спрямована на розвиток здібностей людини, на набуття нею певних професійно необхідних умінь і навичок. Значна роль у цьому відведена соціальному і психологічному консультуванню.

Ключові слова: майбутній соціальний працівник, консультування, соціально-психодогічний тренінг, уміння і навички, професійна підготовка, професійна компетентність. 